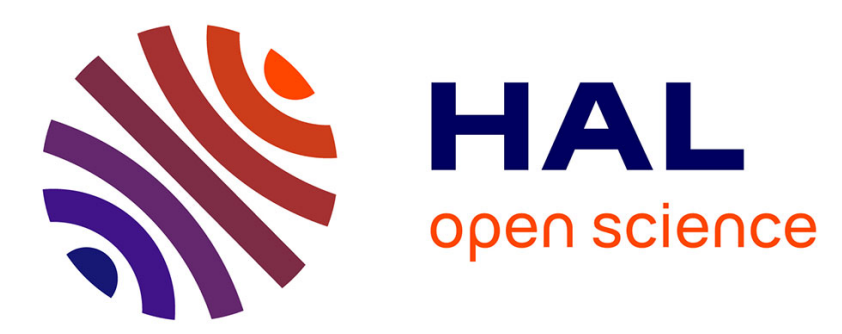

\title{
Thermal stability study of NiAl2O4 binders for Chemical Looping Combustion application
}

Lucia Blas, Patrick Dutournié, Sophie Dorge, Ludovic Josien, Damaris Kehrli, Arnold Lambert

\section{- To cite this version:}

Lucia Blas, Patrick Dutournié, Sophie Dorge, Ludovic Josien, Damaris Kehrli, et al.. Thermal stability study of NiAl2O4 binders for Chemical Looping Combustion application. Fuel, 2016, 182, pp.50-56. 10.1016/j.fuel.2016.05.080 . hal-01398800

\section{HAL Id: hal-01398800 https://hal.science/hal-01398800}

Submitted on 2 Feb 2017

HAL is a multi-disciplinary open access archive for the deposit and dissemination of scientific research documents, whether they are published or not. The documents may come from teaching and research institutions in France or abroad, or from public or private research centers.
L'archive ouverte pluridisciplinaire HAL, est destinée au dépôt et à la diffusion de documents scientifiques de niveau recherche, publiés ou non, émanant des établissements d'enseignement et de recherche français ou étrangers, des laboratoires publics ou privés. 
Thermal stability study of $\mathrm{NiAl}_{2} \mathrm{O}_{4}$ binders for Chemical Looping Combustion application

Lucia Blas ${ }^{\mathrm{a},{ }^{*}}$, Patrick Dutournié ${ }^{\mathrm{b}}$, Sophie Dorge ${ }^{\mathrm{c}}$, Ludovic Josien ${ }^{\mathrm{b}}$, Damaris Kehrli ${ }^{\mathrm{c}}$, Arnold Lambert $^{\mathrm{d}}$

${ }^{a}$ NS3E, ISL-CNRS-UNISTRA (Nanomatériaux pour les Systèmes Sous Sollicitations Extrêmes) UMR 3208, French-German Research Institute of Saint-Louis 5, rue du Général Cassagnou, BP 70034, 68301 St Louis, France.

*Corresponding author: luciablas@gmail.com, phone: +33 3896956 72; fax: +33 389695074

${ }^{b}$ Institut de Science des Matériaux de Mulhouse (IS2M), UMR 7361 CNRS-Université de Haute-Alsace (UHA), 3 bis, rue Alfred Werner, 68093 Mulhouse, France patrick.dutournie@uha.fr, phone: +33 3893367 52; ludovic.josien@uha.fr,phone: +33 3893368 21; 3 bis, rue Alfred Werner, 68093 Mulhouse, France. sophie.dorge@uha.fr, phone: +33 3893361 59; damaris.kehrli@uha.fr,phone: +33 3893361 68;

${ }^{d}$ IFP Energies nouvelles, Rond-point de l'échangeur de Solaize, BP 3, 69360 Solaize, France arnold.lambert@ifpen.fr, phone: +33 43770 29 30;

\begin{abstract}
The influence of the preparation method of $\mathrm{NiAl}_{2} \mathrm{O}_{4}$ binders on their thermal stability was studied. For this purpose, the reactivity of two different $\mathrm{NiAl}_{2} \mathrm{O}_{4}$ binders with $\mathrm{CO}$ as fuel was 25 studied in a fixed bed reactor device. Successive oxidation-reduction cycles were performed
\end{abstract}


on the two binders to study their reactivity with the fuel and their structural modifications as cycles proceed. Results reveal that binders are not inert in reducing atmosphere; they both react with the fuel to produce $\mathrm{CO}_{2}$. The total reduction capacity (TRC) of the first binder (B1, synthetized by pyrolytic pulverization) increases during the first cycles and levels off after 20

5 cycles. However, the TRC of the second binder (B2, synthetized by calcination of a mixture of $\mathrm{Ni}(\mathrm{OH})$ and $\gamma-\mathrm{Al}_{2} \mathrm{O}_{3}$ ), increases progressively and reaches a maximum after 80 cycles. The growing amount of available oxygen in the binders leads both binders to structural modifications. X-Ray Diffraction studies performed on fresh and aged binders presented a shift of the peaks related to $\mathrm{NiAl}_{2} \mathrm{O}_{4}$. Moreover, quantitative X-Ray Diffraction studies and Temperature Programmed Reduction measurements were performed in order to quantify the $\mathrm{NiO}$ present in each binder before and after oxidation-reduction cycles. These experiments revealed the presence of $\mathrm{NiO}$ in fresh binders due to the preparation method, and an increase of this amount after oxidation-reduction cycles. Therefore, $\mathrm{NiAl}_{2} \mathrm{O}_{4}$ in the binder is progressively decomposed producing $\mathrm{NiO}$ and $\mathrm{Al}_{2} \mathrm{O}_{3}$. Finally, the decomposition of the binder $\mathrm{NiAl}_{2} \mathrm{O}_{4}$ as cycles proceed was also observed in studies performed on the oxygen carrier $\mathrm{NiO} / \mathrm{NiAl}_{2} \mathrm{O}_{4}$. This work showed that the binder reacts with the fuel and therefore it can contribute to the modification of the oxygen carrier reactivity.

Keywords: Oxygen Carrier, $\mathrm{NiAl}_{2} \mathrm{O}_{4}$ binder, X-Ray Diffraction, Standard Addition Method, Temperature Programmed Reduction

\section{Introduction}

To limit the increase of greenhouse gas emissions and stabilize climate at safe levels, $\mathrm{CO}_{2}$ capture and sequestration technologies are nowadays being studied and developed [1]. Among these, Chemical Looping Combustion (CLC) has been suggested as an interesting alternative 
of an indirect combustion, where the oxygen needed for fuel oxidation is provided by a solid oxygen carrier. During this process, the fuel is first oxidized by the oxygen carrier and the latter is afterwards regenerated (re-oxidized) by air [4]. The most common CLC device consists of two interconnected fluidized beds (“combustion” and "regeneration” reactors) with

5 a circulation of the solid oxygen carrier. However Noorman et al. [5-6] also proposed the possibility of working in a packed bed reactor where the oxygen carrier remains static and the different oxidation/reduction gas mixtures are alternatively injected. Gases produced in the combustion reactor are primarily $\mathrm{CO}_{2}$ and $\mathrm{H}_{2} \mathrm{O}$. Thus, after water condensation, pure $\mathrm{CO}_{2}$ is obtained and it can be directly stored or used. Outlet gases from the regeneration step (depleted air) can be directly emitted to the atmosphere. In conclusion, power generation by CLC technology does not require an energy intensive gas separation of $\mathrm{CO}_{2}$ from exhaust gases, which is the most expensive step of $\mathrm{CO}_{2}$ capture and sequestration.

Finding suitable oxygen carriers with sufficient reactivity, good mechanical properties and stability is strategic to increase the efficiency of CLC processes. Oxygen carriers are generally composed of an active phase (generally a metal oxide based on $\mathrm{Ni}, \mathrm{Fe}, \mathrm{Cu}, \mathrm{Mn}$ or $\mathrm{Co}$ ) and a porous binder $\left(\mathrm{Al}_{2} \mathrm{O}_{3}, \mathrm{NiAl}_{2} \mathrm{O}_{4}, \mathrm{SiO}_{2}, \mathrm{TiO}_{2}\right.$, yttrium-stabilized zirconia...), which provides higher surface area for reaction, mechanical strength and attrition resistance [7-8]. The final properties of the oxygen carrier (reactivity, mechanical strength, thermal and chemical stability...) depend mainly on the metal oxide used, but also on the binder, as well as the preparation method. Several methods have been studied in the literature and can be classified in three groups:

- Mixing of metal oxide and binder powders (mechanical mixing [9-10], freeze granulation [11-12], spray drying [13-14], spin flash [15-16]...).

- $\quad$ Preparation by precipitation (co-precipitation [17-18], sol-gel [19-20]...).

- $\quad$ Preparation by impregnation (wet and incipient wetness impregnation...) [21-22]. 
The Freeze granulation is the most common preparation method at laboratory scale. However, only spray drying, spin flash and impregnation methods can be used at large scale for industrial production.

Numerous materials based on $\mathrm{Ni}, \mathrm{Fe}, \mathrm{Cu}, \mathrm{Mn}$ and $\mathrm{Co}$ oxides have been studied and tested as oxygen carriers for CLC, at different working scales (laboratory and pilot scale) [7-10]; [17]; [21-35]. Among all these candidates, $\mathrm{NiO} / \mathrm{NiAl}_{2} \mathrm{O}_{4}$ oxygen carrier is considered as a model oxygen carrier, due to its high reactivity and its good thermal stability. Indeed, it can work at high temperatures $\left(900-1100^{\circ} \mathrm{C}\right)$ owing to the high melting points of $\mathrm{NiO}$ and metallic $\mathrm{Ni}$ [7], [9], [17], [23]. For these reasons Ni-based oxygen carriers are widely studied at laboratory scale, however their use should be minimized at industrial scale due to the high toxicity of this metal and health/safety issues.

Among all the possible metal oxide/binder combinations, some authors studied the use of $\boldsymbol{\gamma}$ $\mathrm{Al}_{2} \mathrm{O}_{3}$ as a binder for $\mathrm{NiO}$, but they observed that at high operating temperatures $\left(>800^{\circ} \mathrm{C}\right)$ the binder reacts with $\mathrm{NiO}$ to form $\mathrm{NiAl}_{2} \mathrm{O}_{4}$ [17], [36], [37]. $\mathrm{NiAl}_{2} \mathrm{O}_{4}$ is less reactive with fuel 15 for CLC operations, although it can be partially reduced by the fuel[38]. Thus, the formation of $\mathrm{NiAl}_{2} \mathrm{O}_{4}$ reduces the amount of $\mathrm{NiO}$ able to deliver oxygen for combustion and so, the global performance of the oxygen carrier. To avoid the decrease of reactivity due to $\mathrm{NiAl}_{2} \mathrm{O}_{4}$ formation, Cho et al. [39] studied adding nickel in excess to get enough free $\mathrm{NiO}$ inside the particle and compensate for the loss of "reactive" nickel species. They showed that the initial

$20 \mathrm{NiO}$ content must be very high (around 80 wt. \%) to obtain a $\mathrm{NiO}$ free content of 60 wt. \%. Gayán et al. [7] demonstrated that the formation of the spinel $\mathrm{NiAl}_{2} \mathrm{O}_{4}$ depends on the crystalline nature of the binder. They proposed to use a thermal treatment (at $1150^{\circ} \mathrm{C}$ ) to perform the phase transformation of $\gamma-\mathrm{Al}_{2} \mathrm{O}_{3}$ to $\alpha-\mathrm{Al}_{2} \mathrm{O}_{3}$, in order to improve binder thermal stability. Results showed that the use of $\alpha-\mathrm{Al}_{2} \mathrm{O}_{3}$ partially reduced the formation of $\mathrm{NiAl}_{2} \mathrm{O}_{4}$. 
Furthermore, Jin et al. [40] suggested to use $\mathrm{NiAl}_{2} \mathrm{O}_{4}$ directly as a binder instead of $\mathrm{Al}_{2} \mathrm{O}_{3}$. Afterwards, several authors studied the performances of the oxygen carrier $\mathrm{NiO} / \mathrm{NiAl}_{2} \mathrm{O}_{4}$ and they generally observed high reactivity towards oxidation of different fuels $\left(\mathrm{CH}_{4}\right.$, syngas...) and high stability. The reactivity of $\mathrm{Al}_{2} \mathrm{O}_{3}$ (used as binder) with $\mathrm{NiO}$ to form $\mathrm{NiAl}_{2} \mathrm{O}_{4}$ was studied by Adánez et al. [41] and Dueso et al. [36], [42]. Adánez et al. [41] studied methane combustion (30 vol. \% in $\mathrm{N}_{2}$ ) in a CLC plant of 500 Wth during 100 hours. The oxygen carrier used for this study was composed of 18 wt. \% of $\mathrm{NiO}$ and 82 wt. $\%$ of $\alpha-\mathrm{Al}_{2} \mathrm{O}_{3}$. They observed that $\alpha-\mathrm{Al}_{2} \mathrm{O}_{3}$ reacted partially with $\mathrm{NiO}$ at high temperature to produce $\mathrm{NiAl}_{2} \mathrm{O}_{4}$. Moreover, their results revealed that both phases ( $\mathrm{NiO}$ and produced $\mathrm{NiAl}_{2} \mathrm{O}_{4}$ ) could react with the fuel. Therefore, $\mathrm{NiAl}_{2} \mathrm{O}_{4}$ (used as binder or produced by reaction between $\mathrm{NiO}$ and the binder $\mathrm{Al}_{2} \mathrm{O}_{3}$ ) cannot be considered as an inert material in CLC processes: it is an additional source of oxygen for combustion [43]. The experiments also showed that the relative amount of free $\mathrm{NiO}$ in the oxygen carrier (after metal oxide $\mathrm{NiO}$ and binder $\mathrm{Al}_{2} \mathrm{O}_{3}$ reaction) depends on the oxygen carrier/fuel ratio $(\phi)$. Therefore, the production of $\mathrm{NiAl}_{2} \mathrm{O}_{4}$

15 decreased when $\phi$ decreased. Dueso et al. [36] performed thermogravimetric analyses simulating oxidation/reduction cycles with the same oxygen carrier $\left(\mathrm{NiO} / \alpha-\mathrm{Al}_{2} \mathrm{O}_{3}\right)$ and $\mathrm{CH}_{4}$ as fuel. They observed that the produced $\mathrm{NiAl}_{2} \mathrm{O}_{4}$ was less reactive than $\mathrm{NiO}$. Furthermore, there was a direct relation between oxygen carrier conversion during the reduction step and the proportion of free $\mathrm{NiO}$ and $\mathrm{NiAl}_{2} \mathrm{O}_{4}$ present in the oxygen carrier after re-oxidation. $80 \%$ of nickel reduced in the previous cycle was reoxidized into free $\mathrm{NiO}$ while the rest was reoxidised into $\mathrm{NiAl}_{2} \mathrm{O}_{4}$ (fresh oxygen carrier composition: 18 wt. $\mathrm{NiO}, 82$ wt. \% $\mathrm{Al}_{2} \mathrm{O}_{3}$; final composition: 14.4 wt. $\% \mathrm{NiO}, 77$ wt. $\% \mathrm{Al}_{2} \mathrm{O}_{3}$ and 8.6 wt. $\% \mathrm{NiAl}_{2} \mathrm{O}_{4}$ ). However, these authors have not studied the reactivity of the binder $\mathrm{NiAl}_{2} \mathrm{O}_{4}$ alone.

The stability of the nickel aluminate binder used in CLC is a very important parameter to ensure good mechanical strength of the oxygen carrier, and so, limit particles agglomeration 
and fragmentation which could damage the CLC process. In previous work [43], we studied the reactivity of the $\mathrm{NiAl}_{2} \mathrm{O}_{4}$ binder by performing oxidation/reduction cycles in a fixed bed reactor with $\mathrm{CO}$ as fuel. The major observation was that the binder underwent a structural modification, which modified its reactivity. X-Ray Diffraction analyses showed that peaks related to $\mathrm{NiAl}_{2} \mathrm{O}_{4}$ were enlarged and shifted to wide diffraction angles. These results were explained by the gradual decomposition of $\mathrm{NiAl}_{2} \mathrm{O}_{4}$ to produce $\mathrm{NiO}$ and $\gamma-\mathrm{Al}_{2} \mathrm{O}_{3}$. The purpose of the present work is to study the influence of the preparation method on the reactivity and stability of the binder $\mathrm{NiAl}_{2} \mathrm{O}_{4}$ and to quantify the amount of $\mathrm{NiO}$ produced by decomposition of the $\mathrm{NiAl}_{2} \mathrm{O}_{4}$ spinel phase during successive reduction/oxidation experiments.

The reactivity of two different binders was studied in a fixed bed reactor with $\mathrm{CO}$ as fuel. The evolution of both binders, in terms of reactivity and structural changes, was also investigated by the measurement of the amount of produced $\mathrm{CO}_{2}$ during successive cycles.-The materials were analyzed by X-Ray Diffraction and Temperature Programmed Reduction to quantify the amount of $\mathrm{NiO}$ present in both materials before and after oxidation/reduction cycles. Additional tests were performed to compare the evolution of nickel aluminate in the binders and in the oxygen carrier $\left(\mathrm{NiO} / \mathrm{NiAl}_{2} \mathrm{O}_{4}\right)$.

\section{Experimental section}

\subsection{Materials}

Two $\mathrm{NiAl}_{2} \mathrm{O}_{4}$ binders were studied in this work. Cabot Corp. synthetized the first one (noted as B1) by spray pyrolysis of a mixture of nickel nitrate $\mathrm{Ni}\left(\mathrm{NO}_{3}\right)_{2}$ and gamma alumina $\gamma-\mathrm{Al}_{2} \mathrm{O}_{3}$ (spectral 100). Afterwards the mixture was calcined at $800^{\circ} \mathrm{C}$ and $1000^{\circ} \mathrm{C}$ (during 24 hours at each temperature). The material was pelletized by IFP Energies Nouvelles (Solaize, France), these pellets were ground and sieved to obtain particle sizes between 125 and $300 \mu \mathrm{m}$. 
The preparation of the second binder (noted as B2) was performed by IFP Energies Nouvelles (Solaize, France). A mixture of nickel hydroxide $\mathrm{Ni}(\mathrm{OH})$ and gamma alumina $\gamma-\mathrm{Al}_{2} \mathrm{O}_{3}$ was calcined at $1200^{\circ} \mathrm{C}$ during 24 hours. The material was pelletized, ground and sieved to 100 and $300 \mu \mathrm{m}$. While calcining binder $\mathrm{B} 1$ at $1000^{\circ} \mathrm{C}$ was enough to obtain nearly pure $\mathrm{NiAl}_{2} \mathrm{O}_{4}$,

5 the second preparation method required an increase of the calcination temperature up to $1200^{\circ} \mathrm{C}$ for most of the nickel oxide to react with alumina and produce $\mathrm{NiAl}_{2} \mathrm{O}_{4}$. Despite this very high calcination temperature, some $\mathrm{NiO}$ was still unreacted (vide infra).

Both binders were characterized by X-Ray Diffraction, analyses were performed in Lindemann tubes with the same quantity of material for each sample. Peak identification was carried out by means of the PDF (Powder Diffraction File) database.

An oxygen carrier $\mathrm{NiO} / \mathrm{NiAl}_{2} \mathrm{O}_{4}$ was also studied in this work. The composition of the oxygen carrier was 60 wt. \% metallic oxide $(\mathrm{NiO})$ and 40 wt. \% of binder $\left(\mathrm{NiAl}_{2} \mathrm{O}_{4}\right)$ and it was supplied by IFP Energies nouvelles (Solaize, France). The particles were first produced by granulation in a Guedu granulator and then calcined at $1200^{\circ} \mathrm{C}$ for 2 hours under air flow. Only particles in the range between 100 and $300 \mu \mathrm{m}$ were used in this study.

\subsection{Experimental set-up}

Several oxidation-reduction cycles were performed on all materials in a fixed bed reactor device described in previous work [44], [45]. The binder was placed in a quartz reactor with an inner diameter of $6 \mathrm{~mm}$. The mass introduced (around $0.2 \mathrm{~g}$ ) was estimated to have a bed height of around $5 \mathrm{~mm}$. The reactor was heated by a tubular furnace (Pekly/HerrmannMoritz), and the operating temperature was measured by two thermocouples placed above and below the material bed. The fuel used in this study was carbon monoxide ([CO] $=0.55$ vol. \% in $\mathrm{N}_{2}$ ), and the regeneration step was carried out under air. All gas flow rates were controlled

25 and maintained constant at $50 \mathrm{NL} \mathrm{h}^{-1}$ by four mass flow controllers (BROOKS 5850). The 
gases concentrations $\left(\mathrm{CO}\right.$ and $\left.\mathrm{CO}_{2}\right)$ at the outlet of the reactor were continuously measured by an infrared analyzer NG2000 (CO and $\mathrm{CO}_{2}$ concentration in the range 0-1 vol. \%).

\subsection{Experimental methodology}

5 Oxidation / reduction cycling experiments started with an oxidation step, carried out under air from ambient temperature to the operating temperature (heating rate of $10^{\circ} \mathrm{C} \mathrm{min}^{-1}$ ). When operating temperature was reached, an inerting step was performed under pure $\mathrm{N}_{2}$ to avoid contact between fuel and air. Afterwards, a mixture of $\mathrm{CO} / \mathrm{N}_{2}$ was injected in the reactor (reduction step) at the operating temperature. The reaction was finished when the CO concentration at the reactor's outlet was the same as the inlet concentration. The material was finally cooled down to ambient temperature under inert atmosphere and a new oxidation step could be started (new cycle).

\subsection{Sample characterization}

X-Ray Diffraction (XRD) analyses were performed using a PAN analytical, X'Pert Pro diffractometer operating with $\mathrm{Cu} \mathrm{K} \alpha$ radiation $(\lambda=0.15418 \mathrm{~nm})$ equipped with a $\mathrm{X}$ 'Celerator detector. Measurements were achieved for $2 \theta$ angles in the $10-90^{\circ}$ range, by step of $0.02^{\circ}$ (220 s per step).

Temperature Programmed Reduction (TPR) experiments were performed in a SDT Q-600 thermobalance of TA Instruments. Operating conditions for TPR experiments were: $6 \mathrm{NL} \mathrm{h}^{-1}$ of $\mathrm{H}_{2} / \mathrm{N}_{2}$ (5 vol. \%) gas flow rate and $2^{\circ} \mathrm{C} \min ^{-1}$ of temperature heating ramp, from ambient temperature to $1200^{\circ} \mathrm{C}$.

Surface area analysis by krypton adsorption were performed on aged samples (after several oxidation-reduction cycles) using a Micromeritics ASAP 2420 apparatus. 


\section{Results}

3.1 Evolution of the Total Reduction Capacity (TRC) of binders B1 and B2 as cycles proceed Two binders stability and reactivity were studied under the same operating conditions: $0.2 \mathrm{~g}$ of material (B1 or B2), $900^{\circ} \mathrm{C}, 0.55$ vol. \% of $\mathrm{CO}$ as fuel in $\mathrm{N}_{2}$, gas flow rate fixed at $50 \mathrm{NL}$

$5 \mathrm{~h}^{-1}$. The Total Reduction Capacity (TRC) was the parameter chosen to study the evolution of the materials reactivity. TRC corresponds to the number of $\mathrm{CO}_{2}$ moles produced per gram of material, and it is calculated by the integration of the $\mathrm{CO}_{2}$ breakthrough curves obtained during the reduction step. Oxidation-reduction cycles were performed with both binders (B1 and B2) until the TRC stabilisation. The results obtained with each binder are represented in figure 1 for the $\mathrm{CO}_{2}$ concentration curves and in table 1 for the TRC values.

The $\mathrm{CO}_{2}$ curves obtained on both binders clearly indicate a notable activity of the materials in the oxidation of CO. This activity could partially be explained by the presence of residual $\mathrm{NiO}$ in the materials due to the preparation method. However, the amount of $\mathrm{CO}_{2}$ produced clearly increases as cycles proceed for binders B1 and B2, indicating an evolution of the oxidizing ability of the two binders. Indeed, this TRC increase (table 1) cannot solely be explained by the presence of residual $\mathrm{NiO}$.

As it is observed in table 1, TRC of B1 increases during the first cycles and tends to level off (after 20 cycles), whereas for B2, TRC increases progressively and converges slowly to the maximal TRC (after 80 cycles). If we consider that only $1 / 4$ of the oxygen in $\mathrm{NiAl}_{2} \mathrm{O}_{4}$ is available to oxidize CO (we consider that the oxygen of alumina is not available at all), $75 \%$ of this oxygen reacts in $\mathrm{B} 1$ during the $20^{\text {th }}$ cycle, and $43 \%$ for $\mathrm{B} 2$ during the $80^{\text {th }}$ cycle. During the first reduction cycle, the amount of available oxygen which reacts is equal to $56 \%$ and $10 \%$ for $\mathrm{B} 1$ and $\mathrm{B} 2$ respectively. In conclusion, at $900^{\circ} \mathrm{C}$, a non-negligible amount of oxygen is available in both binders, which does not only come from residual $\mathrm{NiO}$ in the fresh materials. The growing amount of available oxygen in the binders as cycles proceed shows 
structural modifications of the two binders that depend on the preparation method. Indeed, reactivity and stability of B1 and B2 during oxidation-reduction cycles are not the same. B1 reacts more rapidly than $\mathrm{B} 2$ and generates more available oxygen.

\subsection{Binder characterization by X-Ray Diffraction investigation}

Both binders were characterized by X-Ray Diffraction (XRD) to understand the evolution of their structures. XRD analyses were performed on the fresh and the aged binders (after successive cycles). On the fresh binders, two different crystalline phases with cubic structure were identified: $\mathrm{NiO}$ (ICDD PDF 00-047-1049) and $\mathrm{NiAl}_{2} \mathrm{O}_{4}$ (ICDD PDF 01-081-0715). The principal peaks of $\mathrm{NiO}$ and $\mathrm{NiAl}_{2} \mathrm{O}_{4}$ are represented in figure 2. The nickel and aluminum were introduced in stoechiometric proportions $\left(\frac{N i}{A l}=1\right)$. XRD patterns show the presence of NiO traces, which leads us to suppose that there are traces of alumina in the mixture. For binder $\mathrm{B} 1$, as the diffraction peaks of $\gamma-\mathrm{Al}_{2} \mathrm{O}_{3}$ are at $2 \theta$ angles close to the $\mathrm{NiAl}_{2} \mathrm{O}_{4}$ ones, it is impossible to distinguish traces of alumina in the fresh material. However, low intensity peaks

15 of $\alpha-\mathrm{Al}_{2} \mathrm{O}_{3}$ are detected in fresh B2 (ICDD PDF 00-046-1212) $(2 \theta=57.4$ and 68.1). The presence of $\mathrm{NiO}$ and $\alpha-\mathrm{Al}_{2} \mathrm{O}_{3}$ traces in this material is due to the preparation method (the reactants did not fully react to produce $\mathrm{NiAl}_{2} \mathrm{O}_{4}$ ). The alumina present in $\mathrm{B} 2$ is in its alpha polymorph because of the high calcination temperature used for its preparation $\left(1200^{\circ} \mathrm{C}\right)$. Indeed, at temperatures higher than $1100^{\circ} \mathrm{C}$, there is a phase transformation from $\gamma-\mathrm{Al}_{2} \mathrm{O}_{3}$ to $\alpha-\mathrm{Al}_{2} \mathrm{O}_{3}$.

As it was observed in previous studies [43], XRD analyses reveal a shift and an enlargement of the peaks related to $\mathrm{NiAl}_{2} \mathrm{O}_{4}$ for both aged binders, while $\mathrm{NiO}$ peaks remain at the same diffraction angles. These observed shifts reveal a structural modification of both binders as cycles proceed. It seems that the peaks of $\mathrm{NiAl}_{2} \mathrm{O}_{4}$ shift towards $\gamma-\mathrm{Al}_{2} \mathrm{O}_{3}$ angles (cubic phase 
Fd-3m). This observation could be explained by the progressive decomposition of $\mathrm{NiAl}_{2} \mathrm{O}_{4}$ to form $\mathrm{NiO}$ and $\gamma-\mathrm{Al}_{2} \mathrm{O}_{3}$. Moreover, for the aged binder $\mathrm{B} 2$, a diffraction peak $\left(2 \theta=66.6^{\circ}\right)$ appears corresponding to $\gamma-\mathrm{Al}_{2} \mathrm{O}_{3}$. This hypothesis seems to be confirmed by the evolution of TRC during experiments, which increases for both binders. Indeed, NiO produced at high

5 temperature is probably the compound which reacts with $\mathrm{CO}$ and which progressively increases TRC.

\subsection{Quantitative estimation of NiO content in the binders}

\subsubsection{Quantification by X-Ray Diffraction analyses: Standard Addition Method}

To estimate the $\mathrm{NiO}$ content present in each binder, quantitative XRD analyses were 10 performed by using the Standard Addition Method (SAM). This standard method is used in analytical chemistry and has the advantage of eliminating possible matrix effects due to the analyzed sample which can modify the values obtained by quantitative measurements. Particularly in XRD analyses, the shape of the diffraction patterns can be modified by the difference of X-ray adsorption coefficients according to the mass and the composition of the

15 sample. This method consists in measuring the response (in this case, the surface area of the integrated $\mathrm{NiO}$ diffraction peaks) for each successive addition (known masses) of the analyte $\mathrm{NiO}$ to the binder. 3 peaks of $\mathrm{NiO}$ were considered to perform the calculations. For example, figure 3 represents an enlargement of four XRD patterns corresponding to the fresh binder B2 and for three $\mathrm{NiO}$ additions. For each standard addition, the surface of the $\mathrm{NiO}$ peaks increases while the surface of the peaks related to $\mathrm{NiAl}_{2} \mathrm{O}_{4}$ remain almost constant.

The integration of the $\mathrm{NiO}$ peaks is systematically corrected by the integration of six peaks relative to $\mathrm{NiAl}_{2} \mathrm{O}_{4}$ for each standard addition.

Finally, the initial mass fraction of $\mathrm{NiO}$ of the binders (before addition, noted $\% \mathrm{NiO}(0)$ ) is obtained by representing the ratio between mass fraction of $\mathrm{NiO}$ (addition $\mathrm{k}$ ) calculated from 
weighted masses versus exactly the same function calculated by peak integration (equation I). The initial content of $\mathrm{NiO}(\% \mathrm{NiO}(0))$ is estimated by adjusting the latter to have a straight line with a slope equal to 1 and passing through the origin (first bisector). This mathematical analysis reduces classical calculation errors carried out by estimation of the slope and the interception of a linear curve. A minimum of four points (initial content +3 additions) were used in calculations for a good precision.

$$
y=\frac{\% N i O(k)}{\% N i O(0)}=f\left(\frac{\% N i A l_{2} O_{4}(0)}{\% N i A l_{2} O_{4}(k)} \times \frac{\frac{1}{n} \sum_{i=1}^{n} \frac{s_{N i O}^{i}(k)}{s_{N i O}^{i}(0)}}{\frac{1}{m} \sum_{j=1}^{m} \frac{s_{N i A l_{2} O_{4}}{ }^{(k)}}{s_{N i A l_{2} O_{4}}^{j}(0)}}\right)
$$

$\mathrm{S}$ corresponds to the surface of the peak of test $\mathrm{k}$, $\mathrm{i}$ the number of peak related to $\mathrm{NiO}(\mathrm{i}=1$ to $n=3)$, $j$ the number of peak related to $\mathrm{NiAl}_{2} \mathrm{O}_{4}(\mathrm{j}=1$ to $\mathrm{m}=6)$. The initial experiment (without addition) is named 0 .

This procedure was used for the four studied samples (fresh B1 and B2 and after oxidationreduction cycles). The best fit lines obtained have in all cases a correlation coefficient $\left(\mathrm{R}^{2}\right)$ higher than 0.999 (figure 4).

Table 2 shows the NiO mass fraction of the four samples (fresh and aged B1 and B2) estimated by using the Standard Addition Method

The results presented in table 2 confirm the observations obtained from TRC measurements. The initial $\mathrm{NiO}$ contents in the fresh binders are not equal: $\mathrm{B} 1$ contains more residual $\mathrm{NiO}$ than B2, which can explain the higher value of TRC obtained during the first cycle (3.17 moles $\mathrm{CO}_{2} / \mathrm{mg}$ for $\mathrm{B} 1$ against 0.59 moles $\mathrm{CO}_{2} / \mathrm{mg}$ for $\mathrm{B} 2$ ). The $\mathrm{NiO}$ content of the two 20 binders increases as cycles proceed and can be explained by a decomposition of nickel aluminate to form $\mathrm{NiO}$ and probably alumina. These results show that nickel aluminate is 
reacting with the fuel from the first cycle $(0.75$ and 0.23 moles of $\mathrm{NiO}$ per milligram of $\mathrm{B} 1$ and B2 respectively).

\subsubsection{NiO content estimation by Temperature Programmed Reduction measurements}

5 To confirm the X-Ray Diffraction data, Temperature Programmed Reduction (TPR) experiments were performed with the same samples (fresh and aged B1 and B2). These experiments consist in the reduction of the different crystalline phases contained in the two binders ( $\mathrm{NiO}$ and $\mathrm{NiAl}_{2} \mathrm{O}_{4}$ ) which occurs at different temperatures under a $\mathrm{H}_{2}$ gas flow. Alumina is probably present in the sample, but does not react with $\mathrm{H}_{2}$. TPR investigations were conducted in a thermobalance, where mass variations were measured as a function of temperature with a slow ramp of temperature to ensure separation of the two reductions of $\mathrm{NiO}$ and $\mathrm{NiAl}_{2} \mathrm{O}_{4}$. The operating conditions were: $8 \mathrm{mg}$ of sample, gas flow rate $6 \mathrm{NL} \mathrm{h}^{-1}, 5$ vol. $\% \mathrm{H}_{2}$ in nitrogen, $2^{\circ} \mathrm{C} \min ^{-1}$ heating rate, from ambient temperature to $1200^{\circ} \mathrm{C}$. Results obtained for the fresh and the aged B1and B2 are presented in figure 5.

Figures 5 shows the mass variation and its first derivative as a function of temperature for each studied material. In all cases we observe a first mass loss between $350^{\circ}$ and $600^{\circ} \mathrm{C}$ corresponding to the reduction of $\mathrm{NiO}$ and a second one at temperatures higher than $600^{\circ} \mathrm{C}$ corresponding to the reduction of $\mathrm{NiAl}_{2} \mathrm{O}_{4}$. The $\mathrm{NiO}$ content of each material have been estimated from this data and are given in table 2.

\subsubsection{Discussion}

Both quantitative X-Ray Diffraction analyses and TPR experiments confirm that the NiO content present in both binders increases as oxidation-reduction experiments are performed. 
From these results, the partial decomposition of the spinel phase $\mathrm{NiAl}_{2} \mathrm{O}_{4}$ to form $\mathrm{NiO}$ and $\mathrm{Al}_{2} \mathrm{O}_{3}$ is demonstrated and quantified. This decomposition and its kinetics depend on the binder's preparation method. Indeed, binder B2 obtained with a higher calcination temperature $\left(1200^{\circ} \mathrm{C}\right)$ generates lower quantities of available oxygen than binder $\mathrm{B} 1$. The 5 binder $\mathrm{B} 2$ is also less reactive. These observations can be explained by the fact that the surface available for reaction is higher for B1 $\left(31.5 \mathrm{~m}^{2} \mathrm{~g}^{-1}\right)$ than for B2 $\left(2.9 \mathrm{~m}^{2} \mathrm{~g}^{-1}\right)$ (measured by krypton adsorption after several oxidation-reduction cycles).

The TPR analyses indicate the same trend. The reduction reaction of NiO present in the two binders started approximately at the same temperature (around $350^{\circ} \mathrm{C}$ ), whereas $\mathrm{NiAl}_{2} \mathrm{O}_{4}$ starts to reduce around $600^{\circ} \mathrm{C}$ for $\mathrm{B} 1$ and around $700^{\circ} \mathrm{C}$ for B2. In both cases (binders $\mathrm{B} 1$ and B2), the peaks related to $\mathrm{NiAl}_{2} \mathrm{O}_{4}$ reduction shift to higher temperatures after numerous cycles. These results could be the consequence of accessibility decrease of reaction sites $\left(\mathrm{NiAl}_{2} \mathrm{O}_{4}\right)$ due to the presence of alumina and nickel. Some authors [46] observed an influence of the calcination temperature on the final reactivity of the material. They postulate that a higher calcination temperature leads to a less reactive binder. Moreover, these shifts could not be explained by a diffusion limitation in the particles. Han et al. [47] did a comprehensive analysis of the diffusion limitations of a very similar system and demonstrated that the internal diffusion resistance was significant only for particles with mean diameter greater than $1.0 \mathrm{~mm}$.

Gayán et al. [10] performed comparative reactivity studies of different NiO-based oxygen carriers prepared by dry impregnation and supported on $\gamma-\mathrm{Al}_{2} \mathrm{O}_{3}$ (21 wt. \% of $\mathrm{NiO}$ ) or on $\alpha-$ $\mathrm{Al}_{2} \mathrm{O}_{3}$ (11-38 wt. \% of NiO). They observed that using $\gamma-\mathrm{Al}_{2} \mathrm{O}_{3}$ as a binder, most of the impregnated $\mathrm{NiO}$ reacted to form $\mathrm{NiAl}_{2} \mathrm{O}_{4}$, therefore the reactivity of the oxygen carrier decreased. On the other side, if $\alpha-\mathrm{Al}_{2} \mathrm{O}_{3}$ was used as binder, the reactivity between the 
alumina and $\mathrm{NiO}$ was decreased, less $\mathrm{NiAl}_{2} \mathrm{O}_{4}$ was produced, and the reactivity of the oxygen carrier was higher.

Our present results show that nickel aluminate partially decomposes to form nickel oxide and alumina $\left(\mathrm{NiAl}_{2} \mathrm{O}_{4}=\mathrm{NiO}+\mathrm{Al}_{2} \mathrm{O}_{3}\right)$ under reducing conditions. This chemical decomposition

5 seems to reach a thermodynamic equilibrium after several cycles. At the beginning (in the fresh binder) the reaction quotient is almost zero (no products) and $\mathrm{NiO}$ and $\mathrm{Al}_{2} \mathrm{O}_{3}$ are preferably generated (until the reaction quotient is inferior to the equilibrium constant). Moreover, during the reduction step, the reduction of nickel oxide (to produce metallic $\mathrm{Ni}$ ) leads to a decrease of the reaction quotient and so, to the decomposition of nickel aluminate. In these operating conditions, the reaction is slow (in terms of kinetics), because 20 and 80 successive cycles are necessary to reach the equilibrium for binder B1 and B2 respectively.

\subsection{Binder evolution in the oxygen carrier $\mathrm{NiO} / \mathrm{NiAl}_{2} \mathrm{O}_{4}$}

To check if results obtained with the binder $\left(\mathrm{NiAl}_{2} \mathrm{O}_{4}\right)$ could be extrapolated to the oxygen carrier $\left(\mathrm{NiO} / \mathrm{NiAl}_{2} \mathrm{O}_{4}\right)$, a long reduction cycle ( 8 hours) at $900^{\circ} \mathrm{C}$ was performed with the oxygen carrier. The aim is to sufficiently reduce the oxygen carrier to observe $\mathrm{NiAl}_{2} \mathrm{O}_{4}$ reduction, despite the high content of $\mathrm{NiO}$ present in the material (60 wt. \% of $\mathrm{NiO}$ ). After reduction, the obtained material was oxidized and analyzed by XRD. Figure 6 shows the XRD pattern (enlargement between 57 and $69^{\circ}$ ) of the fresh and the reduced $\mathrm{NiO} / \mathrm{NiAl}_{2} \mathrm{O}_{4}$.

20 The figure reveals (as with the binder alone) that peaks relative to $\mathrm{NiO}$ are at the same diffraction angles before and after oxidation reduction cycles, whereas peaks related to $\mathrm{NiAl}_{2} \mathrm{O}_{4}$ are enlarged and shifted to wider diffraction angles. As it was previously deduced for the binder, this shift shows a decomposition of $\mathrm{NiAl}_{2} \mathrm{O}_{4}$ to form $\mathrm{NiO}$ and $\mathrm{Al}_{2} \mathrm{O}_{3}$. These results demonstrate that the binder in the oxygen carrier $\mathrm{NiO} / \mathrm{NiAl}_{2} \mathrm{O}_{4}$ can also react with the fuel 
during the reduction phase, producing additional NiO. The major role of the binder is to ensure the stability of the oxygen carrier and good mechanical properties. However the binder reactivity with the fuel modifies the oxygen carrier performance.

\section{Conclusion}

Oxidation-reduction cycles performed on both binders showed that they cannot be considered as inert materials, because they react with the fuel. The evolution of the Total Reduction Capacity revealed that the reactivity of the two binders is different, and it depends on their synthesis method. The first binder (B1) has a higher initial content of NiO (5.6 wt. \% by XRD and 6.2 wt. \% by TPR) and its Total Reduction Capacity increases during the first cycles and reaches a maximum after 20 oxidation-reduction cycles. The aged binder has a final amount of 17.3 wt. \% calculated by XRD, $24 \%$ by TPR. An increase of the NiO content is also observed on the second binder, from 1.7\% (XRD and TPR) to $11.8 \%$ (XRD); $15.8 \%$ (TPR). The Total Reduction Capacity levels off after 80 cycles. Two different methods have been used in this work to calculate the NIO content present in these materials. Results obtained by both methods are in good agreement for lower contents of $\mathrm{NiO}$ and their deviations increase moderately for higher contents. These results are in good agreement with experimental measurements of Total Reduction Capacity.

The increase of $\mathrm{NiO}$ present in binder is explained by the progressive decomposition of $\mathrm{NiAl}_{2} \mathrm{O}_{4}$ to produce $\mathrm{NiO}$ and $\mathrm{Al}_{2} \mathrm{O}_{3}$. Moreover, the decomposition of the binder as cycles proceed, was also observed on the oxygen carrier $\left(\mathrm{NiO} / \mathrm{NiAl}_{2} \mathrm{O}_{4}\right)$. This study revealed the influence of the preparation method on the binder final reactivity.

\section{References}


[1] MacDowell N, Florin N, Buchard A, Hallett J, Galindo A, Jackson G, Adjiman CS, Williams CK, Shah N, Fennell P. An overview of $\mathrm{CO}_{2}$ capture technologies. Energy Environ Sci 2010; 3: 1645-1669.

[2] Ishida M, Jin H. A new advanced power-generation system using chemical-looping combustion. Energy 1994; 19: 415-422.

[3] Ishida M, Zheng D, Akehata T. Evaluation of a chemical-looping-combustion powergeneration system by graphic exergy analysis. Energy 1987; 12: 147-154.

[4] Lyngfelt A, Leckner B, Mattisson T. A fluidized-bed combustion process with inherent $\mathrm{CO}_{2}$ separation; application of chemical-looping combustion. Chem Eng Sci; 56: 31013113.

[5] Noorman S, van Sint Annaland M, Kuipers JAM. Packed Bed Reactor Technology for Chemical-Looping Combustion. Ind Eng Chem Res 2007; 46: 4212-4220.

[6] Noorman S, van Sint Annaland M, Kuipers JAM. Experimental validation of packed bed chemical-looping combustion. Chem Eng Sci 2010; 65: 92-97.

[7] Gayán P, de Diego LF, García-Labiano F, Adánez J, Abad A, Dueso C. Effect of support on reactivity and selectivity of Ni-based oxygen carriers for chemical-looping combustion. Fuel 2008; 87: 2641-2650.

[8] Adanez J, Abad A, Garcia-Labiano F, Gayan P, de Diego LF. Progress in ChemicalLooping Combustion and Reforming technologies. Prog Energy Combust Sci 2012; 38: 215-282.

[9] Adánez J, de Diego LF, García-Labiano F, Gayán P, Abad A, J. M. Palacios JM. Selection of Oxygen Carriers for Chemical-Looping Combustion. Energy Fuels 2004; 18: 371-377.

[10] de Diego LF, García-Labiano F, Adánez J, Gayán P, Abad A, Corbella BM, Palacios JM. Development of Cu-based oxygen carriers for chemical-looping combustion. Fuel 2004; 83: 1749-1757.

[11] Mattisson T, Johansson M, Lyngfelt A. The use of $\mathrm{NiO}$ as an oxygen carrier in chemical-looping combustion. Fuel 2006; 85: 736-747.

[12] Jerndal E, Mattisson T, Lyngfelt A. Thermal Analysis of Chemical-Looping Combustion. Chem Eng Res Des 2006; 84: 795-806.

[13] Jerndal E, Mattisson T, Thijs I, Snijkers F, Lyngfelt A. Investigation of $\mathrm{NiO} / \mathrm{NiAl}_{2} \mathrm{O}_{4}$ oxygen carriers for chemical-looping combustion produced by spray-drying. Int $\mathrm{J}$ Greenh Gas Control 2010; 4: 23-35.

[14] Kuusik R, Trikkel A, Lyngfelt A, Mattisson T. High temperature behavior of NiO-based oxygen carriers for Chemical Looping Combustion. Energy Procedia 2009; 1: 38853892.

[15] Linderholm C, Abad A, Mattisson T, Lyngfelt A. 160 h of chemical-looping combustion in a $10 \mathrm{~kW}$ reactor system with a NiO-based oxygen carrier. Int J Greenh Gas Control 2008; 2: 520-530.

[16] Leion H, Lyngfelt A, Mattisson T. Solid fuels in chemical-looping combustion using a NiO-based oxygen carrier. Chem Eng Res Des 2009; 87: 1543-1550.

[17] Villa R, Cinzia C, Gianpiero G, Luca L, Pio F, Ugo C, Stefano R. Ni based mixed oxide materials for $\mathrm{CH}_{4}$ oxidation under redox cycle conditions. J Mol Catal 2003; 204: 637646.

[18] Lambert A, Delquié C, Clémeneçon I, Comte E, Lefebvre V, Rousseau J, Durand B. Synthesis and characterization of bimetallic Fe/Mn oxides for chemical looping combustion. Energy Procedia 2009; 1: 375-381.

[19] Ishida M, Jin H, Okamoto T. A Fundamental Study of a New Kind of Medium Material for Chemical-Looping Combustion. Energy Fuels 1996; 10: 958-963.

[20] Zhao H, Liu L, Wang B, Xu D, Jiang L, Zheng C. Sol-Gel-Derived $\mathrm{NiO} / \mathrm{NiAl}_{2} \mathrm{O}_{4}$ 
Oxygen Carriers for Chemical-Looping Combustion by Coal Char. Energy Fuels 2008; 22: 898-905.

[21] Mattisson T, Johansson M, Lyngfelt A. Multicycle Reduction and Oxidation of Different Types of Iron Oxide Particles Application to Chemical-Looping Combustion. Energy Fuels 2004; 18: 628-637.

[22] Mattisson T, Järdnäs A, Lyngfelt A. Reactivity of Some Metal Oxides Supported on Alumina with Alternating Methane and OxygenApplication for Chemical-Looping Combustion. Energy Fuels 2003; 17: 643-651.

[23] Abad A, Adánez J, García-Labiano F, de Diego LF, Gayán P, Celaya J. Mapping of the range of operational conditions for $\mathrm{Cu}-$, Fe-, and Ni-based oxygen carriers in chemicallooping combustion. Chem Eng Sci 2007; 62: 533-549.

[24] Hossain MM, de Lasa HI. Chemical-looping combustion (CLC) for inherent separations-a review. Chem Eng Sci 2008; 63: 4433-4451.

[25] Abad A, Mattisson T, Lyngfelt A, Johansson M. The use of iron oxide as oxygen carrier in a chemical-looping reactor. Fuel 2007; 86: 1021-1035.

[26] Yang J, Cai N, Li Z. Reduction of Iron Oxide as an Oxygen Carrier by Coal Pyrolysis and Steam Char Gasification Intermediate Products. Energy Fuels 2007; 21: 3360-3368.

[27] Corbella BM, Palacios JM. Titania-supported iron oxide as oxygen carrier for chemicallooping combustion of methane. Fuel 2007; 86: 113-122.

[28] Ishida M, Takeshita K, Suzuki K, Ohba T. Application of $\mathrm{Fe}_{2} \mathrm{O}_{3}-\mathrm{Al}_{2} \mathrm{O}_{3}$ Composite Particles as Solid Looping Material of the Chemical-Loop Combustor. Energy Fuels 2005; 19: 2514-2518.

[29] García-Labiano F, de Diego LF, Adánez J, Abad A, Gayán P. Reduction and Oxidation Kinetics of a Copper-Based Oxygen Carrier Prepared by Impregnation for ChemicalLooping Combustion. Ind Eng Chem Res 2004; 43: 8168-8177.

[30] Forero CR, Gayán P, de Diego LF, Abad A, García-Labiano F, Adánez J. Syngas combustion in a 500 Wth Chemical-Looping Combustion system using an impregnated Cu-based oxygen carrier. Fuel Process Technol 2009; 90: 1471-1479.

[31] Johansson M, Mattisson T, Lyngfelt A. Investigation of $\mathrm{Mn}_{3} \mathrm{O}_{4}$ with Stabilized $\mathrm{ZrO}_{2}$ for Chemical-Looping Combustion. Chem Eng Res Des 2006; 84: 807-818.

[32] Forutan HR, Karimi E, Hafizi A, Rahimpour MR, Keshavarz P. Expert representation chemical looping reforming: A comparative study of $\mathrm{Fe}, \mathrm{Mn}, \mathrm{Co}$ and $\mathrm{Cu}$ as oxygen carriers supported on $\mathrm{Al}_{2} \mathrm{O}_{3}$. J Ind Eng Chem 2015; 21: 900-911.

[33] Abad A, Mattisson T, Lyngfelt A, Rydén M. Chemical-looping combustion in a $300 \mathrm{~W}$ continuously operating reactor system using a manganese-based oxygen carrier. Fuel 2006; 85: 1174-1185.

[34] Gu Z, Li K, Wang H, Qing S, Zhu X, Wei Y, Cheng X, Yu H, Cao Y. Bulk monolithic $\mathrm{Ce}-\mathrm{Zr}-\mathrm{Fe}-\mathrm{O} / \mathrm{Al}_{2} \mathrm{O}_{3}$ oxygen carriers for a fixed bed scheme of the chemical looping combustion: Reactivity of oxygen carrier. Appl Energy 2016; 163: 19-31.

[35] Wang J, Zhao H. Evaluation of CaO-decorated $\mathrm{Fe}_{2} \mathrm{O}_{3} / \mathrm{Al}_{2} \mathrm{O}_{3}$ as an oxygen carrier for insitu gasification chemical looping combustion of plastic wastes. Fuel 2016; 165: 235243.

[36] Dueso C, Abad A, García-Labiano F, de Diego LF, Gayán P, Adánez J, Lyngfelt A. Reactivity of a $\mathrm{NiO} / \mathrm{Al}_{2} \mathrm{O}_{3}$ oxygen carrier prepared by impregnation for chemicallooping combustion. Fuel 2010; 89: 3399-3409.

[37] Gayán P, Dueso C, Abad A, Adanez J, de Diego LF, García-Labiano F. NiO/ $\mathrm{Al}_{2} \mathrm{O}_{3}$ oxygen carriers for chemical-looping combustion prepared by impregnation and deposition-precipitation methods. Fuel 2009; 88: 1016-1023.

[38] Cheng Z, Wu Q, Li J, Zhu Q. Effects of promoters and preparation procedures on reforming of methane with carbon dioxide over $\mathrm{Ni} / \mathrm{Al}_{2} \mathrm{O}_{3}$ catalyst. Catal Today 1996; 30: 
147-155.

[39] Cho P, Mattisson T, Lyngfelt A. Carbon Formation on Nickel and Iron OxideContaining Oxygen Carriers for Chemical-Looping Combustion. Ind Eng Chem Res 2005; 44: 668-676.

5 [40] Jin H, Okamoto T, Ishida M. Development of a Novel Chemical-Looping Combustion: Synthesis of a Looping Material with a Double Metal Oxide of CoO-NiO. Energy Fuels 1998; 12: 1272-1277.

[41] Adánez J, Dueso C, de Diego F, García-Labiano F, Gayán P, Abad A. Methane Combustion in a 500 Wth Chemical-Looping Combustion System Using an Impregnated Ni-Based Oxygen Carrier. Energy Fuels 2009; 23: 130-142.

[42] Dueso C, Ortiz M, Abad A, García-Labiano F, de Diego LF, Gayán P, Adánez J. Reduction and oxidation kinetics of nickel-based oxygen-carriers for chemical-looping combustion and chemical-looping reforming. Chem Eng J 2012; 188: 142-154.

[43] Blas L, Dorge S, Dutournié P, Lambert A, Chiche D, Bertholin S, Josien L. Study of the performances of an oxygen carrier: Experimental investigation of the binder's contribution and characterization of its structural modifications. Comptes Rendus Chim 2015; 18: 45-55.

[44] Blas L, Dorge S, Zouaoui N, Lambert A, Dutournié P. Influence of the oxidation step on the behaviour and the performances of an oxygen carrier in fixed bed reactor. Mater Res 2014; 17: 219-226.

[45] Blas L, Dorge S, Michelin L, Dutournié P, Lambert A, Chiche D, Bertholin S. Influence of the regeneration conditions on the performances and the microstructure modifications of $\mathrm{NiO} / \mathrm{NiAl}_{2} \mathrm{O}_{4}$ for chemical looping combustion. Fuel 2015; 153: 284-293.

[46] Cesteros Y, Salagre P, Medina F, Sueiras JE. Preparation and Characterization of Several High-Area $\mathrm{NiAl}_{2} \mathrm{O}_{4}$ Spinels. Study of Their Reducibility. Chem Mater 2000, 12 : 331-335.

[47] Han L, Zhou Z, Bollas GM. Heterogeneous modeling of chemical-looping combustion. Part 2: Particle model. Chem Eng Science 2014, 113: 116-128. 